\title{
A Study on the Reservoir Capacity to Control Mud Flood Derived from Mud Volcano: A Phenomenon in Sidoarjo
}

\author{
Mahmud Mustain ${ }^{1}$, Rohmat Ilman Salim ${ }^{1}$, Sholihin ${ }^{1}$, and Sujantoko ${ }^{1}$
}

\begin{abstract}
This paper is an extended research of Coastal Zone Management of Sidoarjo mud phenomenon. The idea is to find special concept of management to control mud flood using reservoir system. This method, in the mud fluid, is intentionally used to make separation of the solid materials from water. The concept is to calculate sediment velocity in order to find the time of sedimentation then to estimate the volume of mud. Therefore, the reservoir will be determined from this calculation. The result of this research is the dimension of the reservoir: area of $3,704,144.36 \mathrm{~m}^{2}$, the depth of $5.94 \mathrm{~m}$, and the volume 22.018.856.07 $\mathrm{m}^{3}$. The time of sedimentation is calculated of 28.33 hours for $42.2 \%$ of material volume sedimentation. Consequently, the suspension material is $57.8 \%$. The correction of calculation is depending on the calculation of the velocity of sedimentation, about $2 \%$.
\end{abstract}

Keywords — mud, Sidoarjo, reservoir, sedimentation

\section{INTRODUCTION}

$\mathrm{T}$ he latest phenomenon of this era in East Java is the mud explosion in Porong Sidoarjo. It has brought some problems especially for the people around the locations [7], [11], and [13]. There have been various methods employed solve the explosion, including an efforts to fix snubbing unit, to apply side tracking, to realize the relief well, and to penetrate the concrete ball. However, the efforts are less successful as the problems remain unsolved until today. Moreover, the weather, during rainy seasons along November to March has even worsened the conditions in Sidoarjo [8].

Recently, there is a solution attempted to stop the explosion by pumping the mud out and making it flow throughout the pipes to the Porong River, the nearest river to the coastal area. However, there are some next constrains i.e. sedimentation and sea transportation problems. Therefore, another effort is promoted to restrict the flow of the mud. This is done by building strong stone walls surrounded the explosion points, so that it resembles to a wide mud flow dam. Furthermore, this attempt is carried out to anticipate the limited capacity of the reservoir.

Unfortunately, remarkable results of all the above efforts are still far off due to the absence of general designs for reservoirs; therefore, in the attempt to find the best solution, this present research aims to search more possibilities to control the impacts derived from the explosion. Instead of flowing the mud into the river in which sedimentation and interruptions on the sea transportations, the present research would attempt to

${ }^{1}$ Mahmud Mustain, Rohmat Ilman Salim, Sholihin, and Sujantoko are with Department of Ocean Engineering, FTK, Institut Teknologi Sepuluh Nopember, Surabaya, 60111, Indonesia. E-mail: mmustain@oe.its.ac.id. propose several attempts, namely, first, widening the reservoir used for the bed load of sedimentation; second, depleting sedimentation in the river after spill way; then, splitting the the reservoir into two parts that are used for sedimentation zone and another part is for suspension zone that is ready for revering. In order to carry out all of the attempts, the present research calculates the rate or velocity of fluid and mud sedimentation; moreover, the study also attempts to measure or estimate the volume of the mud flow that has become a sedimen-tation.

\section{SEDIMENT THEORY AND PROCESS}

There are variation methods of mechanical separation based on the particle motion in fluid dynamic system. It is possibly in phase of gas or liquid either steady or motion condition. The principal of mechanical separation for particle motion from the certain place due to some forces, then the motion will be divided by two stages.

1. Stage one is the short period of acceleration from start condition (zero velocity) to the terminal velocity.

2. Stage two is the period of zero acceleration i.e. the particle in the terminal velocity or constant velocity.

Normally, the acceleration from start condition to the terminal velocity is equal or less than one tenth second. Therefore, it also gives small effect to the particle motion. On the other hand, terminal velocity of the motion gives effect dominantly in the mechanical separation system. Consequently, the command method uses the only period of terminal velocity.

Regarding to the particle concentrate based and viscosity based, there are four types of sediment processes namely:

a. type 1: discrete particle settling,

b. type 2: floculant particle settling,

c. type 3: hindered particle settling,

d. type 4: compression particle settling.

Discrete particle sediment process only depends on the fluid property and particle. It can be described into some simple formulations in fluid mechanic. The particle is assumed that there is no change in the shape, size, and weight along with the sediment process. It is also assumed that the sediment process is only due to gravitational force of the particle. The sediment will be ideal only if the motion is in the steady condition or laminar motion condition.

The particle will move vertically go down if the water density less than the particle density. Table 1 shows the Kinematic viscosity and Dynamic viscosity that depend on the specific weight and mass density. Therefore, it will be reduced by drag force due to the viscosity of water until equilibrium condition i.e. the drag force equal to the gravitational force in the water. This condition is 
called the particle in the motion of terminal settling velocity.

The velocity of sediment is integrally composed by size of particle, shape, hardness, specific gravity, and fluid viscosity. Effective particle force in the water (Impelling force) is the resultant of gravitational force and buoyancy force. It is given by the formulation below:

$W_{s}=F_{v}-F_{b}$

where,

$W_{s} \quad=$ impelling force,

$F_{v} \quad=$ gravitational force,

$F_{b} \quad=$ buoyancy force,

if, $F_{v}=\rho_{s} \cdot g \cdot V_{p}$ and $F_{b}=\rho_{v} \cdot g \cdot V_{p}$

then, $W s=\left(\rho_{s^{-}} \rho_{w}\right) \cdot g \cdot V_{p}$

where,

$\rho_{s} \quad=$ density of particle,

$\rho_{w} \quad=$ density of water,

$g \quad=$ gravity acceleration,

$V_{p} \quad=$ volume of particle.

Drag force of particle in the water is:

$F_{d}=\frac{1}{2} \cdot C_{D} \cdot A_{p} \cdot \rho \cdot V_{s}^{2}$

where,

$F_{d} \quad=$ drag force,

$A_{p} \quad=$ the area of particle proyection,

$V_{s} \quad=$ the velocity of particle motion,

$C_{D} \quad=$ drag coefisien.

Drag coefisien in the function of the shape and Reynolds number $(\mathrm{Re})$.

$\mathrm{C}_{\mathrm{d}}=24 / \mathrm{Re}$

$R_{e}=\left(d_{p} \cdot \rho_{w} \cdot V_{s}\right) / \mu$

where,

$d_{p} \quad=$ diameter of particle,

$\mu \quad=$ dynamic viscosity.

Dynamic viscosity is the multiplication of kinematic viscosity and fluid density, as below:

$v=\frac{\mu}{\rho}$

Drag coefficient can not be calculated analytically if $\operatorname{Re}>2$, Fig. 1. Therefore, drag coefficient has been determined by previous research about velocity of sediment done by Rouse [10], as seen in Fig. 2. The sediment velocity can be calculated by (2) and (3) after $C_{D}$ is determined from the curve of Fig. 1. The supporting scale of $\frac{W_{s}}{\rho} V^{2}$ is needed, because the Re cannot be decided before.

Sediment process will be conducted by constant velocity if the condition is $W_{s}=F_{d}$, then (2) and (3) can be simplified become:

$V_{t}=\sqrt{\left[\frac{2 g\left(\rho_{s}-\rho_{w}\right)}{C_{d}-\rho_{w}}\right]\left[\frac{V_{p}}{A_{p}}\right]}$

If we assume that the particle is sparical shape, then:

$\frac{V_{p}}{A_{p}}=\frac{4 / 3 \pi(d / 2)^{3}}{\pi(d / 2)^{2}}=\frac{2 d_{p}}{3}$
Therefore,

$V_{t}=\sqrt{\left[\frac{4 g}{3 C_{D}}\right]\left[\frac{\rho_{s}-\rho_{w}}{\rho_{w}}\right] \cdot d_{p}}$

If we subtitute (4) and (5) to (9) then we have:

$V_{t}=\frac{1}{18} \frac{\gamma_{s}-\gamma_{w}}{\gamma_{w}} g \frac{d^{2}}{v}$

where,

$\mathrm{dp} \quad=$ diameter particle

$\gamma_{s} \quad=$ specific weight of particle

$\gamma_{w} \quad=$ specific weight of water

This (10) is called Stokes low about terminal settling velocity or sediment velocity [9]. This equation can be used to calculate the sediment velocity for the particle of less than $0.1 \mathrm{~mm}$. The kinematic viscosity is the function of temperature in the formulation below:

$v=\frac{1.79^{2} \times 10^{-6}}{\left(1+0.0337 T+0.000221 T^{2}\right)}$

where, $\mathrm{T}=$ Temperature of water in ${ }^{\circ} \mathrm{C}$.

\section{METHOD}

The study has been carried out by following the procedures below:

1. Making a literary review: after we have decided the definite problems, we need to know the basic theory of sedimentary and the process. At the same time, we make the preliminary survey to understand the general area and also to localize the specific place for sampling and the planning of reservoir area.

2. Collecting data: data required in this present study are the debits of mud flow and the mud sampling. Such data serve as secondary data obtained from the relevant institutions i.e. BPLS.

3. Testing the samples: the test is conducted in Laboratorium Mekanika Tanah dan Batuan Jurusan Teknik Sipil ITS, to obtain the particle density $\left(\rho_{\mathrm{s}}\right)$; the mud (fluid) density $\left(\rho_{\mathrm{w}}\right)$; particle size or particle diameter $\left(\mathrm{d}_{\mathrm{p}}\right)$ and its percentage; dynamic viscosity $(\mu)$; gravity specific $(s)$.

4. Analyzing sedimentation: this produces the velocity of sedimentation that is based on the laboratory test and is graded by the grain size.

5. Estimating the mud volume: the regression of 18 months data of debit has been used to estimate mud volume for certain period.

6. Doing the topographical analysis: the average of elevation of mud has been used to decide the elevation of the damp as well as the possible location of the reservoir.

7. Calculating the depth and time duration of sedimentation: mud volume has been used to calculate the depth and time duration of sedimentation for certain period with variation of velocity sedimentation.

8. Calculating water volume as the rest or residue of sedimentation, suspension, and deposit of sedimentation: the volume of deposit has been calculated based on the time duration of sedimentation with certain velocity of sedimentation. 
9. Calculating time flashing: this is calculation based on the water volume and the debit of water that will be revered, the suspension volume as well as the deposit of sedimentation that will be moved from the reservoir.

10. Calculating of total time: the period of sedimentation duration and time flashing i.e. sum of point 8 and 9.

11. Making reservoir specification: it is based on all results of calculation, shape of reservoir, elevation of damp and maximum capacity of reservoir.

\section{ANALYSIS AND DISCUSSION}

\section{A. Sedimentation Velocity}

The calculation of sedimentation velocity is the implementation of $(10)$ of $[9,4]$. The maximum percentage of particle diameter is $=0.0001 \mathrm{~mm}=0.1 \times 10^{-6} \mathrm{~m}=3.281$ $\mathrm{x} 10^{-7} \mathrm{ft}$. The viscosity kine-matics, $v$ is the function of air temperature $[1,10]$, while the temperature of the mud is $38{ }^{\circ} \mathrm{C}\left(100.4{ }^{\circ} \mathrm{F}\right)$.

$v=1.79^{2} \times 10^{-6} /\left(1+0.0337 T+0.000221 T^{2}\right)$

$=1.79^{2} \times 10^{-6} /\left(1+(0.0337 \times 38)+\left(0.000221 \times 38^{2}\right)\right)$

$=1.79^{2} \times 10^{-6} /(2,5997)$

$=1.232 \times 10^{-6} \mathrm{ft}^{2} / \mathrm{s}$.

The specific weight of water, $\mathrm{lb} / \mathrm{ft}^{3}, \gamma_{\mathrm{w}}$ is measured at the temperature of $28{ }^{\circ} \mathrm{C}\left(82{ }^{\circ} \mathrm{F}\right)$ then it will be get from the characteristic table of $\gamma_{\mathrm{w}}$ of $62,22 \mathrm{lb} / \mathrm{ft}^{3}$. The specific weight of particle $\left(\mathrm{lb} / \mathrm{ft}^{3}\right)$.

$\gamma_{\mathrm{s}}=\mathrm{G}_{\mathrm{s}} \times \gamma_{\mathrm{w}}$

$=2.718 \times 62.22$ (at the measurement condition)

$=169.11 \mathrm{lb} / \mathrm{ft}^{3}$ (from the he characteristic table)

Therefore, sedimentation velocity of the maximum percentage, dominant particle is briefly as:

$$
\begin{aligned}
V_{t}= & \frac{1}{18} \frac{\gamma_{s}-\gamma_{w}}{\gamma_{w}} g \frac{d^{2}}{v} \\
= & 0.0556 \times(169.11-62.22) / 62.22 \times 32.174 \times \\
& \left(3.281 \times 10^{-7}\right)^{2} / 1.232 \times 10^{-6} \\
= & 0.0556 \times 1.718 \times 32.174 \times 8.74 \times 10^{-8} \\
= & 2.68 \times 10^{-7} \mathrm{ft} / \mathrm{s}=8.175 \times 10^{-8} \mathrm{~m} / \mathrm{s} .
\end{aligned}
$$

The sedimentation velocity of each particle diameter is illustrated in Fig. 3.

\section{B. Mud Volume Estimation}

The debit of mud explosion is recorded during 18 monthly records. This is assuming that the data are enough for one annual season such as dry season and wet season. Therefore, the data can be used to make trend line in order to estimate the next period. The result is illustrated in the Fig. 4 with trend line formulation that is created by excel system.

There are three polynomial formulations as mathematical equation of the similar shape. They are equation of third order, fourth order and fifth order as:

$y=299.8 x^{2}-9858 x^{2}+9171 x-999000 ;$

$\mathrm{R}^{2}=0.8708(12)$

$y=13.144 x^{4}-199.6 x^{2}-3640.8 x^{2}+63738 x-66934 ;$

$\mathrm{R}^{2}=0.8877$

$\mathrm{y}=-5.5043 \mathrm{x}^{5}+274.6 \mathrm{x}^{4}-4682.5 \mathrm{x}^{2}+29738 \mathrm{x}^{2}-3739 \mathrm{x}$

+21263 .

$\mathrm{R}^{2}=0.9434$

where, $\mathrm{x}=$ time (month).

The estimate debits of the twentieth month are 190140, 257746, and 30863 respectively for equation of third order, fourth and fifth order. On the other hand, the estimation debits of the twenty fifth month are 717256 , 1266641, and -1978654 respectively as well for equation of third order, fourth and fifth order. The error value is calculated as $0.933,0.942$, and 0.971 also respectively for equation of the third, fourth and fifth order.

The most important thing in this debit case is that we can obtain it from the estimation information in which the debit is clearly fluctuated for several months ahead. This is supposed to hypothesize that in dealing with to the dry season and wet season, we could make the further research to find the geological structure around the location.

\section{Topographical Analysis}

According to the map of distribution of mud, there are some empty areas possible for reservoir location [3]. The location is situated on the South-East of loca-tion of primary eruption crater [5]. Fig. 5 illustrates the most possible location of proposed reservoir. It is also sliced leading to calculate the acre of the area. There are two considerations of reservoir construction:

1. The location of reservoir is close enough to the main damp or levee, in order to make easy and quick to revering of mud.

2. The damp is close to the river Porong, to make short of the distance to water outlet system of reservoir.

The total area for proposed sedimentation reservoir is calculated as:

$$
\begin{aligned}
& \mathrm{A}=\text { area } 1+\text { area } 2+\text { area } 3 \\
& =1425500.69 \mathrm{~m}^{2}+2029585.56 \mathrm{~m}^{2}+249058.10 \mathrm{~m}^{2} \\
& =3704144.36 \mathrm{~m}^{2}
\end{aligned}
$$

\section{Duration of Sedimentation}

Reservoir dimension and duration of sedimentation are identified for all particle size that has variation of sedimentation velocity. It is would be sediment to the base of reservoir. Table 1 shows the alternatives dimension due to the same area (A) and different duration of sedimentation: 1 for one month, 2 for six months, and 3 for twelve months.

Related to Table 2, duration of sedimentation can be calculated for three different velocity. The result is showed in the Table 3, it can also be used to optimize the time duration of sedimentation.

$\mathrm{T}=\mathrm{D} / V_{t}$

where,

$\mathrm{T}=$ time of sedimentation,

$\mathrm{D}=$ dept of reservoir,

$V_{t}=$ sedimentation velocity.

Table 3 shows the variation of sedimentation duration based on the variation of elevations of mud and sedimentation velocity. Sedimentation duration of 32,32 hours are the best alternative (dark line). There are two possible reasons. Firstly, the elevation of mud is reasonable, around 6 meter. Secondly, sedimentation duration is not too long with an appropriate number. The real time duration of sedimentation is the total sedimentation duration of each particle size. Table 4 gives the result of these calculations.

\section{E. Discussion}

Sedimentation duration of 101974.26 (Table 4) seconds or 28.33 hours is appropriate for time flashing of mud volume. The optimal reservoir volume from this calculation is $22018856.07 \mathrm{~m}^{3}$ for next 6 months blow- 
out. The area of $3704144.36 \mathrm{~m}^{2}$ and thickness of mud deposit of 5.94 meters is the best scenario or alternative for the maximum percentage of particle size which is the most appropriate reason. The total water volume for the reservoir is $70 \%$ that is $15413199.25 \mathrm{~m}^{3}$. The volume of sediment is $2787587.18 \mathrm{~m}^{3}$ and the suspension of $3818069.64 \mathrm{~m}^{3}$. Time flashing is calculated as 2113.89 hours or 88.07 days (around 3 months) with dredger capacity of moving out of $\mathrm{Q}=0.4 \mathrm{~m}^{3} / \mathrm{s}$. or a month time flashing for $Q=1.2 \mathrm{~m}^{3} / \mathrm{s}$. The correction of the calculation is depended on the calculation of the velocity of sedimentation. This is about $2 \%$.

If we would like to make a simple discussion for the reservoir function, we have reservoir capacity for 6 months mud explosion that will become sediments within one month, and then it could be dredged in a month, as well. In addition, the shape of reservoir is based on the possible space around main reservoir i.e. in the southeast of area that appropriate to the seismic interpretation [6] and [2]. Fig. 6 is the photograph of mud discharge channels to the Porong River (Kali Porong).

\section{CONCLUSION}

1. The particle size is varied but the maximum percentage of particle size is $0.0001 \mathrm{~mm}$, with velocity of sedimentation of $5.1 \mathrm{E}-05 \mathrm{~m} / \mathrm{s}$.

2. The reservoir capacity is optimized as 22018856.07 $\mathrm{m}^{3}$ for 3 month blowout and a month flashing with dredging capacity of $1.4 \mathrm{~m}^{3} / \mathrm{s}$.

3. The dimension of reservoir is a volume of
$22018856.07 \mathrm{~m}^{3}$. Mud elevation of $5.74 \mathrm{~m}$ and area of $3704144.36 \mathrm{~m}^{2}$.

\section{REFERENCES}

[1] Chih Ted Yang, 1996, "Sediment transport : theory and practice", McGraw-Hill, United States.

[2] Crisp-Nus. www. April 2009. http://www.crisp.nus.edu.sg.

[3] C. David., 2007, "Muddy Waters", NATURE|Vol 445|22 February 2007, Nature Publishing Group, Asia - Pasifik.

[4] Geoffrey S.P. Thomas J. Casadevall and Handoko T. Wibowo. "Preliminary analytical results for a mud sample collected from the LUSI mud volcano. Sidoarjo. East Java. Indonesia". U.S Geological Survey. Reston. Virginia.

[5] W. H. Graf, 1971, "Hydraulics of sediment transport", McGrawHill, New York.

[6] A. Kusumastuti. dkk., 2002, "Seismic sequence analysis and reservoir potential of drowned Miocene carbonate platforms in the Madura Strait. East Java. Indonesia". AAPG Bulletin. Vol. 86. No. 2, February 2002. pp. 213-232.

[7] M, Mustain, 2006, "Fenomena gunung lumpur dan estimasi volume cadangan lumpur Sidoarjo", Prosiding ISNU, ISSN:18296513, Vol. 2, No. 1.

[8] M. Mustain, 2008, "Korelasi timbunan volume lumpur panas terhadap karakter fisik akuifer di wilayah pantai Sidoarjo", Prosiding Teknologi Kelautan FTK-ITS, ISSN 1412-2332, Seminar Nasional Teori dan Aplikasi Teknologi Kelautan, December.

[9] R, Peavy, 1986, "Sediment transport for engineers", McGrawHill, New York.

[10] H. Rouse, 1937, "Fluid mechanics for hydraulic engineers", chapter XI, Dover, New York.

[11] Rovicky. www. November-2006. http://rovicky.wordpress.com/2006/10/12/memetakan-gununglumpur-secara-3dimensi/.

[12] M.J Simith, 1984, "Mekanika tanah", Erlangga. Jakarta.

[13] Simon A. Stewart, 1 Richard J. Davies2, 2006, "Structure and emplacement of mud volcano systems in the South Caspian Basin”, AAPG Bulletin, Vol. 90, No. 5, pp. 771-786.

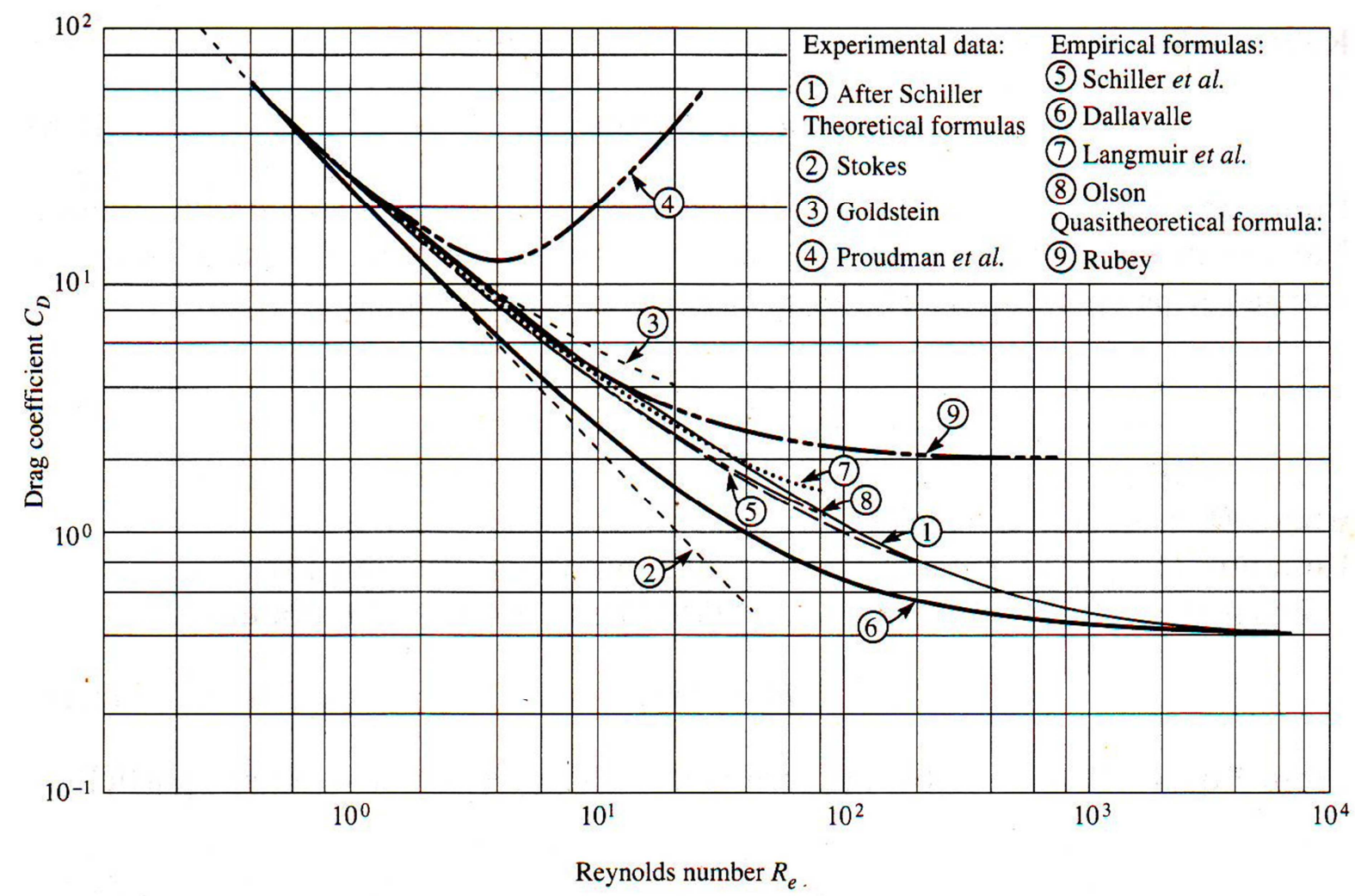

Fig. 1. Drag coefisien and Re number correlation [5] 


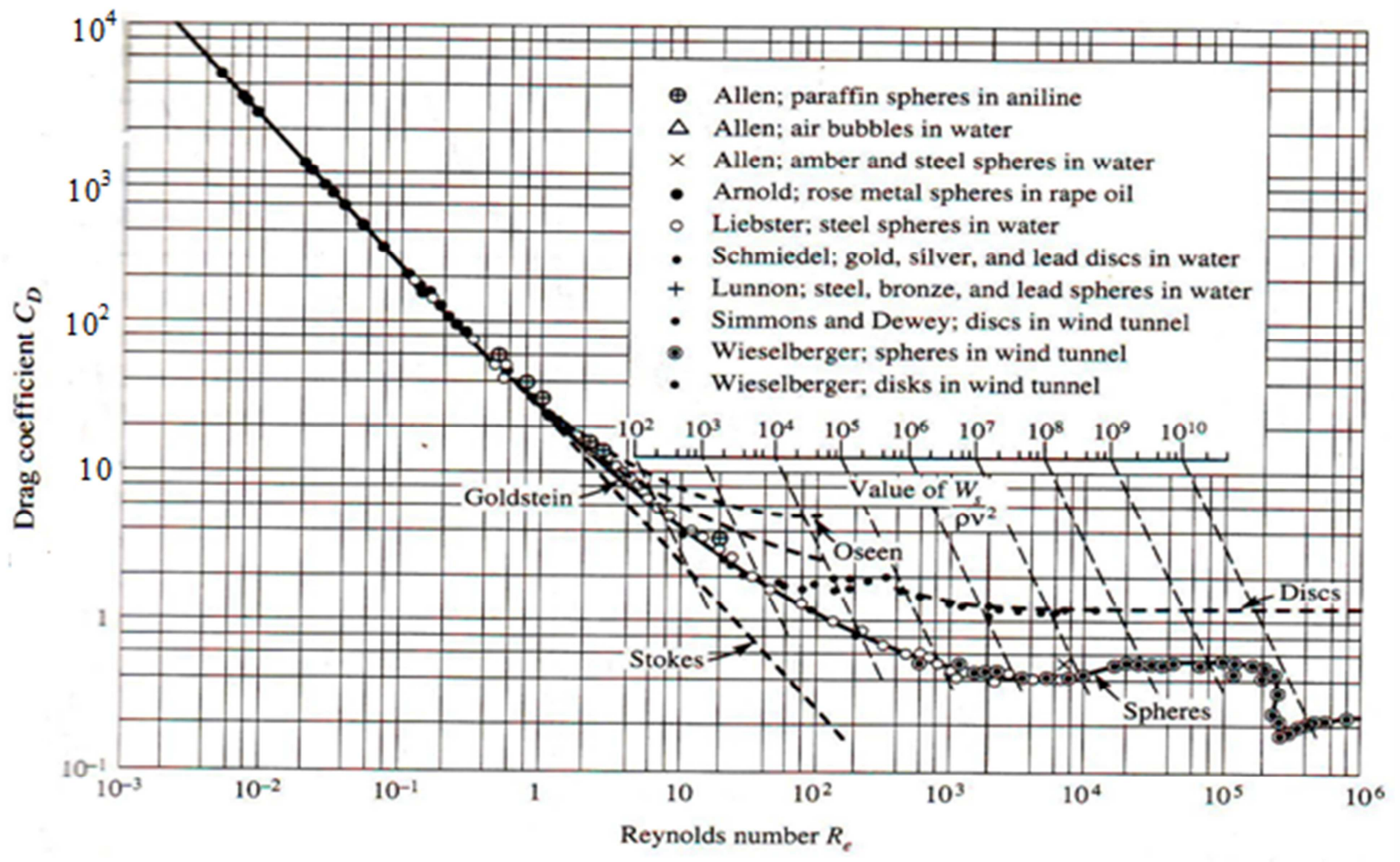

Fig. 2. Drag coefisien [10]

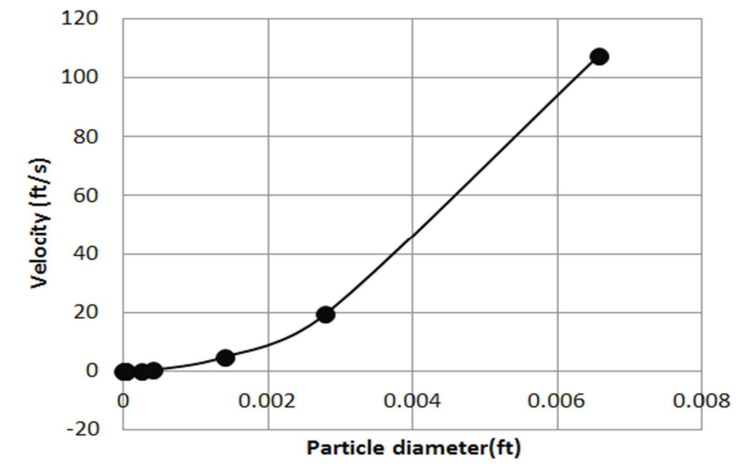

Fig. 3. The profile of sedimentation velocity

TABLE 1.

WATER PROPERTIS

\begin{tabular}{ccccc}
\hline $\begin{array}{c}\text { Temp. } \\
\left({ }^{\circ} \mathrm{F}\right)\end{array}$ & $\begin{array}{c}\text { Specific } \\
\text { Weight } \\
\left(\mathrm{lb} / \mathrm{ft}^{3}\right)\end{array}$ & $\begin{array}{c}\text { Mass } \\
\text { Density } \\
\left(\mathrm{lb} \cdot \mathrm{s}^{2} / \mathrm{ft}^{4}\right)\end{array}$ & $\begin{array}{c}\text { Dynamic } \\
\text { Viscosity } \times 10^{5} \\
\left(\mathrm{lb} \cdot \mathrm{s} / \mathrm{ft}^{2}\right)\end{array}$ & $\begin{array}{c}\text { Kinematic } \\
\text { Viscosity } \times 10^{5} \\
\left(\mathrm{ft}^{2} / \mathrm{s}\right)\end{array}$ \\
\hline 32 & 62.42 & 1.940 & 3.746 & 1.931 \\
40 & 62.43 & 1.940 & 3.229 & 1.664 \\
50 & 62.41 & 1.940 & 2.735 & 1.410 \\
60 & 62.37 & 1.938 & 2.359 & 1.217 \\
70 & 62.30 & 1.936 & 2.050 & 1.059 \\
80 & 62.22 & 1.934 & 1.799 & 0.930 \\
90 & 62.11 & 1.931 & 1.595 & 0.826 \\
100 & 62.00 & 1.927 & 1.424 & 0.739 \\
110 & 61.86 & 1.923 & 1.284 & 0.667 \\
120 & 61.71 & 1.918 & 1.168 & 0.609 \\
130 & 61.55 & 1.913 & 1.069 & 0.558 \\
140 & 61.38 & 1.908 & 0.981 & 0.514 \\
150 & 61.20 & 1.902 & 0.905 & 0.476 \\
160 & 61.00 & 1.896 & 0.838 & 0.442 \\
170 & 60.80 & 1.890 & 0.780 & 0.413 \\
180 & 60.58 & 1.883 & 0.726 & 0.385 \\
190 & 60.36 & 1.876 & 0.678 & 0.362 \\
200 & 60.12 & 1.868 & 0.637 & 0.341 \\
212 & 59.83 & 1.860 & 0.593 & 0.319 \\
\hline
\end{tabular}

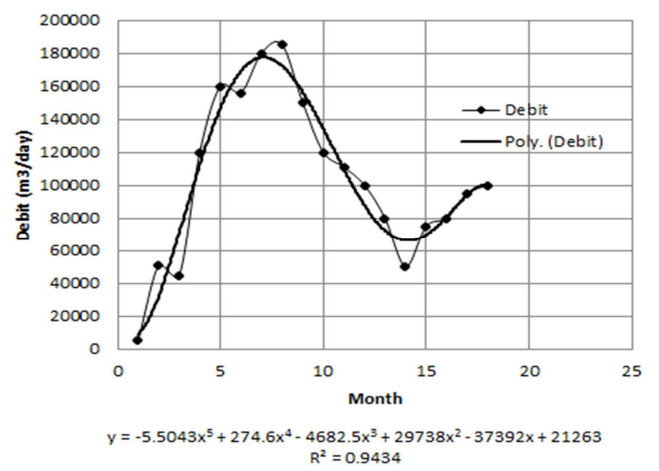

Fig. 4. The curve of mud blow out debit as recorded monthly

TABLE 2 .

ALternAtive OF RESERVOIR DiMENSION WITH ELEVATION MUd OF

\begin{tabular}{cccc}
\multicolumn{4}{c}{ V/A } \\
\hline \multirow{2}{*}{ No } & $\begin{array}{c}\text { Reservoir } \\
\text { Volume }\left(\mathrm{m}^{3}\right)\end{array}$ & $\begin{array}{c}\text { Reservoir } \\
\text { Area }\left(\mathrm{m}^{2}\right)\end{array}$ & $\begin{array}{c}\text { Elevation } \\
\text { Mud(m) }\end{array}$ \\
\hline 1 & 3604485.37 & 3704144.36 & 0.97 \\
2 & 22018856.07 & 3704144.36 & 5.94 \\
3 & 44842710.03 & 3704144.36 & 12.11 \\
\hline
\end{tabular}

TABLE 3.

DECIDING THE RESERVOIR DIMENSION BASED ON THE MINIMUM

\begin{tabular}{ccc}
\multicolumn{3}{c}{ SEDIMENTATION VELOCITY } \\
\hline $\begin{array}{c}\text { Elevation } \\
\text { of Mud } \\
(\mathrm{m})\end{array}$ & $\begin{array}{c}\text { Sediment's } \\
\text { Velocity }(\mathrm{m} / \mathrm{s})\end{array}$ & Sediment's Duration $(\mathrm{h})$ \\
\hline 0.970 & $8.17531 \mathrm{E}-08$ & 3306.350 \\
5.940 & $8.17531 \mathrm{E}-08$ & 20197.61 \\
12.11 & $8.17531 \mathrm{E}-08$ & 41133.64 \\
0.970 & $5.10957 \mathrm{E}-05$ & 5.290000 \\
5.940 & $5.10957 \mathrm{E}-05$ & 32.32000 \\
12.110 & $5.10957 \mathrm{E}-05$ & 65.81000 \\
0.970 & 0.0001 & 2.550000 \\
5.940 & 0.0001 & 15.58000 \\
12.110 & 0.0001 & 31.74000 \\
\hline
\end{tabular}


IPTEK, The Journal for Technology and Science, Vol. 21, No. 4, November 2010

TABLE 4.

Sedimentation Duration of All Particle Size

\begin{tabular}{cccc}
\hline $\begin{array}{c}\text { Particle } \\
\text { Size } \\
(\mathrm{m})\end{array}$ & $\begin{array}{c}\text { Mud } \\
\text { Elevation } \\
(\mathrm{m})\end{array}$ & $\begin{array}{c}\text { Sedimentation } \\
\text { Duration } \\
(\mathrm{s})\end{array}$ & $\begin{array}{c}\text { Sediment } \\
\text { Thickness } \\
(\mathrm{m})\end{array}$ \\
\hline 0.0020000 & 5.94 & 0.18 & 0.01 \\
0.0008500 & 5.93 & 1.00 & 0.02 \\
0.0004250 & 5.92 & 4.01 & 0.07 \\
0.0001250 & 5.87 & 45.97 & 0.19 \\
0.0000750 & 5.75 & 125.07 & 0.64 \\
0.0000097 & 5.30 & 6893.11 & 0.66 \\
0.0000071 & 5.28 & 12810.14 & 0.68 \\
0.0000050 & 5.26 & 25717.81 & 0.71 \\
0.0000036 & 5.23 & 49392.84 & 0.73 \\
0.0000025 & 5.21 & 101974.26 & 0.75 \\
\hline
\end{tabular}

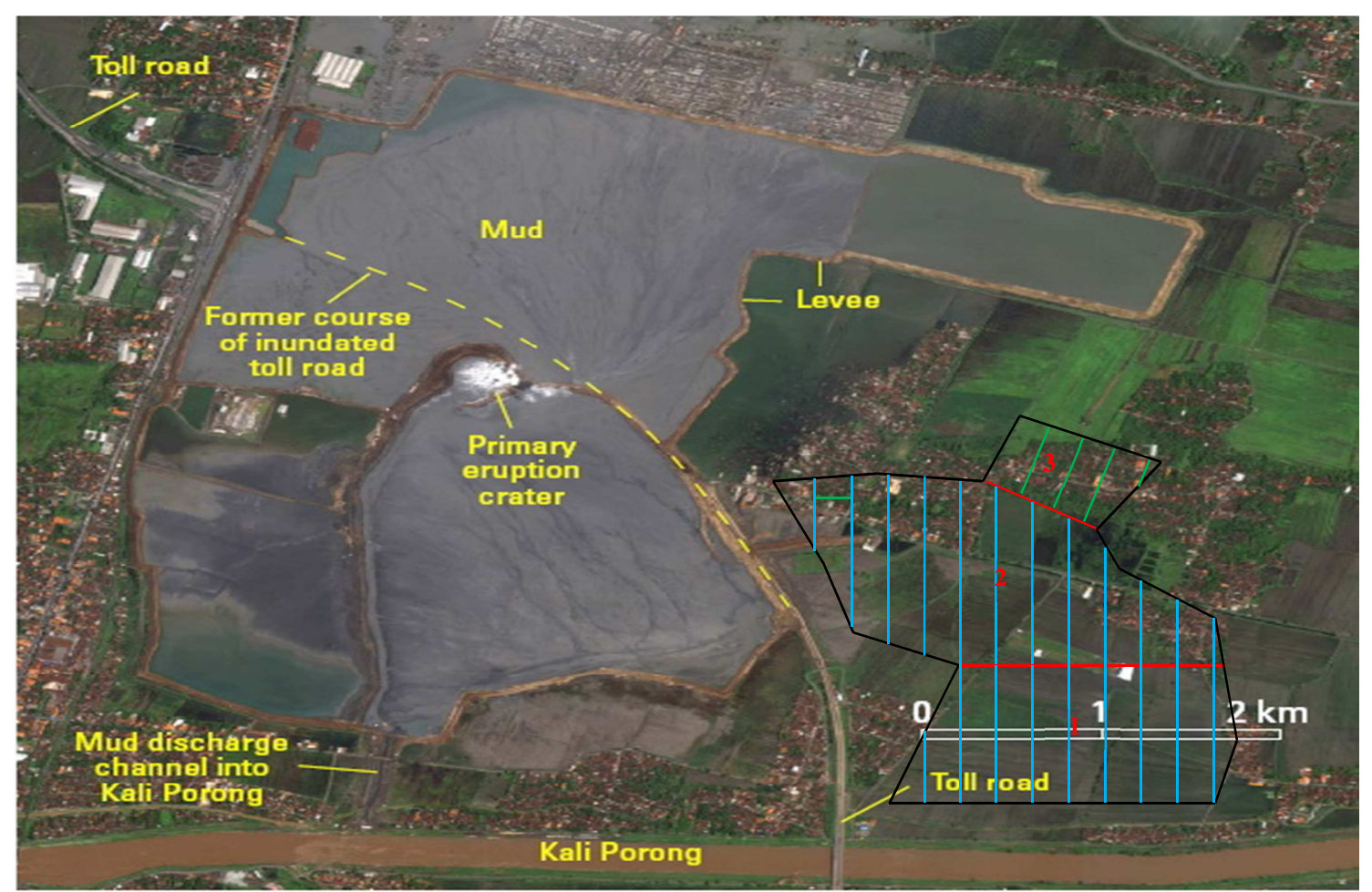

Fig. 5. The sliced area for the calculation of area, area 1,2, and 3

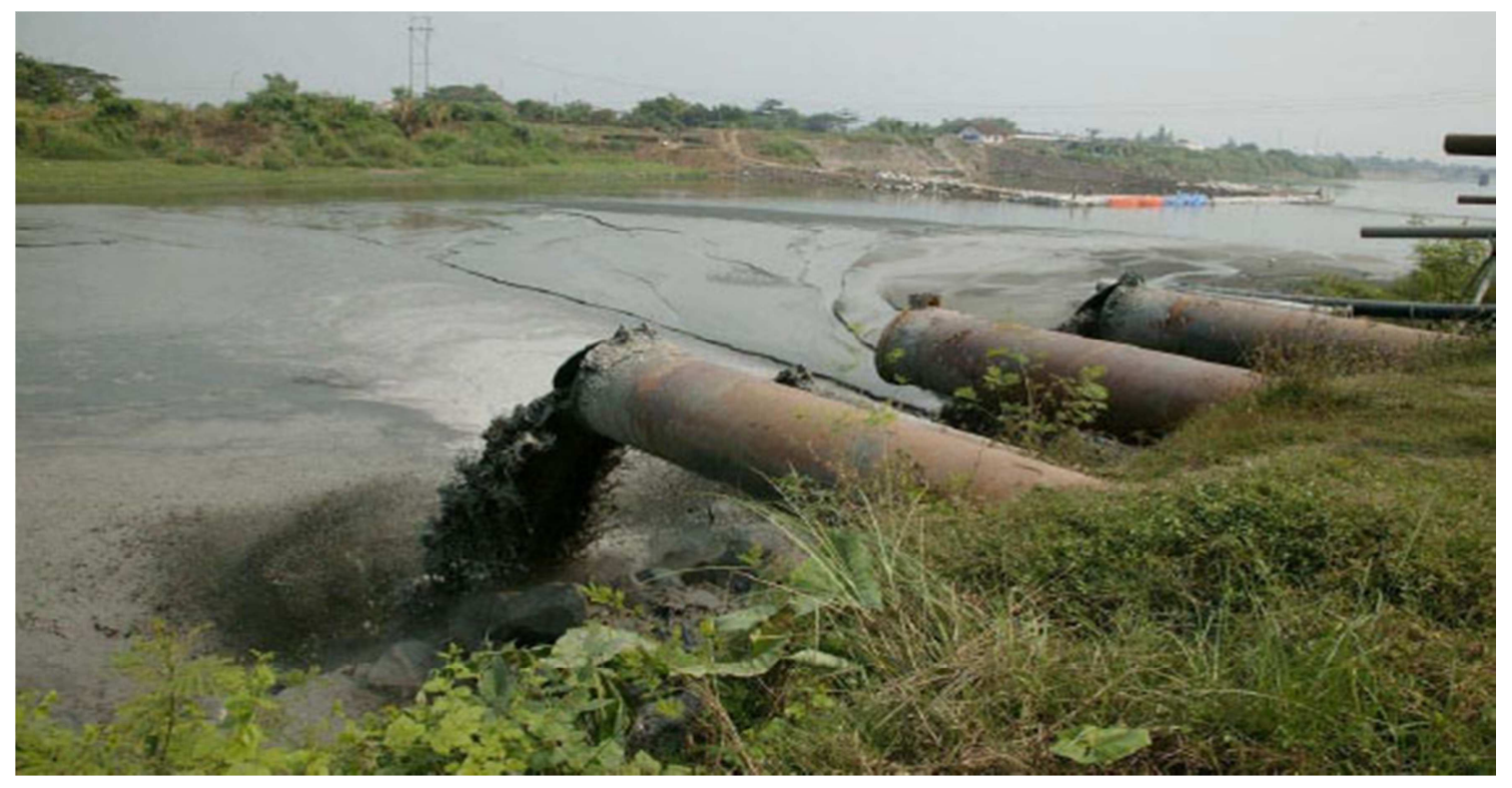

Fig. 6. The mud discharge channels to the Porong River (Kali Porong) 